ISSN 1678-3921

Journal homepage: www.embrapa.br/pab

For manuscript submission and journal contents, access: www.scielo.br/pab

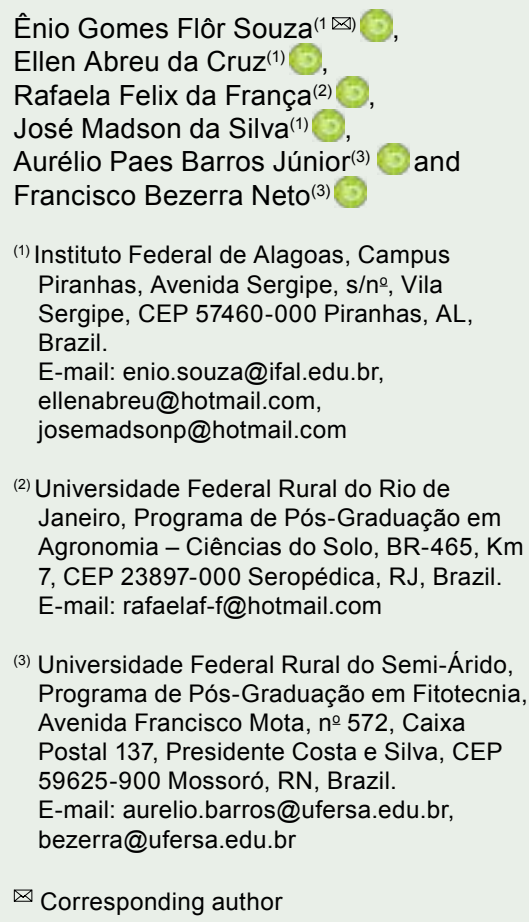

(3) Universidade Federal Rural do Semi-Árido, Programa de Pós-Graduação em Fitotecnia, Avenida Francisco Mota, no 572, Caixa Postal 137, Presidente Costa e Silva, CEP 59625-900 Mossoró, RN, Brazil. E-mail: aurelio.barros@ufersa.edu.br, bezerra@ufersa.edu.br

$\bowtie$ Corresponding author

Received

February 19, 2018

Accepted

April 1, 2019

How to cite

SOUZA, Ê.G.F.; CRUZ, E.A. da; FRANCAA R.F. da; SILVA, J.M. da; BARROS JÚNIOR, A.P.; BEZERRA NETO, F. Economic nitrogen rate for fertigation of green corn crop in the Brazilian semiarid. Pesquisa Agropecuária Brasileira, v.54, e00556, 2019. DOI: https://doi. org/10.1590/S1678-3921.pab2019.v54.00556.

\section{Economic nitrogen rate for fertigation of green corn crop in the Brazilian semiarid}

\begin{abstract}
The objective of this work was to determine the nitrogen rate for fertigation associated with the maximum productivity of green corn (Zea mays) with a lower production cost, in two harvest seasons in the Brazilian semiarid region. The experimental design was a randomized complete block with four replicates, and the treatments consisted of four $\mathrm{N}$ rates $(0,80,160$, and $240 \mathrm{~kg} \mathrm{ha}^{-1}$ ) in form of urea, applied via drip irrigation. The used cultivar was the Bt Feroz hybrid. The evaluated characteristics were: number and mass of marketable ears, gross income, net income, and rate of return. The greatest amounts of marketable ears were reached with $152.52 \mathrm{~kg} \mathrm{ha}^{-1} \mathrm{~N}$ in summer (41,183.84 ears per hectare) and $190.31 \mathrm{~kg} \mathrm{ha}^{-1} \mathrm{~N}$ in winter $(53,291.25$ ears per hectare). In the two harvests, there was a variation in production costs between $\mathrm{R} \$ 2,422.12 \mathrm{ha}^{-1}$ and $\mathrm{R} \$ 3,320.95 \mathrm{ha}^{-1}$ without $\mathrm{N}$ and with 240 $\mathrm{kg} \mathrm{ha}^{-1} \mathrm{~N}$, respectively. The winter harvest showed higher productivity and profitability of green ears with fertigation with $160 \mathrm{~kg} \mathrm{ha}^{-1} \mathrm{~N}$. In the Brazilian semiarid, the maximum productivity of green corn with the lowest production cost is reached with fertigation with $90 \mathrm{~kg} \mathrm{ha}^{-1} \mathrm{~N}$, in both harvests.
\end{abstract}

Index terms: Zea mays, production costs, rate of return.

\section{Dose econômica de nitrogênio para fertirrigação da cultura do milho verde no semiárido brasileiro}

Resumo - O objetivo deste trabalho foi determinar a dose de nitrogênio para fertirrigação associada à máxima produtividade de milho verde (Zea mays) com menor custo de produção, em duas safras agrícolas no semiárido brasileiro. $\mathrm{O}$ delineamento experimental foi em blocos ao acaso, com quatro repetições, e os tratamentos consistiram em doses de $\mathrm{N}(0,80,160$ e $240 \mathrm{~kg}$ $\left.\mathrm{ha}^{-1}\right)$, na forma de ureia, via irrigação por gotejamento. A cultivar utilizada foi o híbrido Bt Feroz. As características avaliadas foram: número e massa de espigas comercializáveis, renda bruta, renda líquida e taxa de retorno. As maiores quantidades de espigas comercializáveis foram alcançadas com $152,52 \mathrm{~kg} \mathrm{ha}^{-1}$ de N no verão (41.183,84 espigas por hectare) e 190,31 $\mathrm{kg} \mathrm{ha}^{-1} \mathrm{de}$ $\mathrm{N}$ no inverno (53.291,25 espigas por hectare). Nas duas safras, houve variação nos custos de produção entre $\mathrm{R} \$ 2.422,12 \mathrm{ha}^{-1}$ e $\mathrm{R} \$ 3.320,95 \mathrm{ha}^{-1}$ sem N e com $240 \mathrm{~kg} \mathrm{ha}^{-1}$ de $\mathrm{N}$, respectivamente. A safra de inverno apresentou maior produtividade e rentabilidade de espigas verdes com fertirrigação com 160 $\mathrm{kg} \mathrm{ha}^{-1}$ de N. No semiárido brasileiro, a máxima produtividade de milho verde com menor custo de produção é alcançada com a fertirrigação com $90 \mathrm{~kg} \mathrm{ha}^{-1}$ de $\mathrm{N}$, em ambas as colheitas.

Termos para indexação: Zea mays, custos de produção, taxa de retorno. 


\section{Introduction}

Green corn (Zea mays L.) is grown in all regions of Brazil and its production is an alternative for irrigated areas in the semiarid of the Northeast region of the country. However, in order to be economically viable and meet the demand of the consumer market, satisfactory yields should be obtained and all factors of production should be at optimal levels. Among these factors, fertilization has an important role in soil fertility and corn mineral nutrition, especially in relation to nitrogen, the nutrient most required by the crop (Von Pinho et al., 2009; Freire et al., 2010).

Studies have shown the beneficial effect of $\mathrm{N}$ rates via manual or mechanical fertilizer distribution on the yield of green corn (Silva et al., 2000, 2013; Paiva et al., 2012; Freire et al., 2010; Araújo et al., 2014; Dantas et al., 2014; Monteiro et al., 2016). However, published article on the application of fertilizers by water (fertigation) in green corn in Brazil were not found, although many corn producers in the country's semiarid already use this technique in drip-irrigation systems, seeking to reduce costs with labor, facilitate the splitting of rates, and increase the uniformity of distribution of fertilizers.

In the United States and India, in addition to the efficiency of $\mathrm{N}$ use by corn, fertigation studies are usually concerned with nutrient losses due to nitrate leaching $\left(\mathrm{NO}_{3}^{-}\right)$because of the risks of groundwater contamination (Sampathkumar \& Pandian, 2010; Kumar et al., 2016). The main recommendations are the application of 75 to $105 \mathrm{~kg} \mathrm{ha}^{-1} \mathrm{~N}$ (Yuan et al., 2017), more frequent irrigations (lower water depths), and fertigation with rates between 30 and $40 \mathrm{~kg} \mathrm{ha}^{-1} \mathrm{~N}$ per application (He et al., 2012).

In semiarid conditions, the risks of $\mathrm{N}$ losses due to the volatilization of ammonia $\left(\mathrm{NH}_{3}\right)$ are greater than those by the leaching of $\mathrm{NO}_{3}^{-}$, and both may be caused by edaphoclimatic factors and cultural practices, such as low organic matter content and soil moisture (Liu et al., 2007), high air temperature (Clay et al., 1990; Tasca et al., 2011), high soil pH values (Sengik et al., 2001; Tasca et al., 2011), and the use of high $\mathrm{N}$ rates in agriculture (Ma et al., 2010; Tasca et al., 2011). Besides influencing $\mathrm{N}$ losses, high air temperatures can also affect the development of corn plants, reducing the cycle and the productive potential of the crop (Paiva Junior et al., 2001; Rosa et al., 2016; Zhou et al., 2017). It should be noted that the rate for maximum physical productivity generally differs from that considered economical, which is subject to the price of the nutrient, other production costs, and the sale prices of the obtained product (Freire et al., 2010; Souza et al., 2015b).

The objective of this work was to determine the nitrogen rate for fertigation associated with the maximum productivity of green corn with a lower production cost, in two harvest seasons in the Brazilian semiarid region.

\section{Materials and Methods}

The experiment was conducted in the field in the summer (January to March) and winter (June to August) crop seasons of 2016, in a property located within an irrigated perimeter supplied with waters of the São Francisco River, in the municipality of Canindé de São Francisco, in the state of Sergipe, in the Brazilian semiarid $\left(9^{\circ} 40^{\prime} 27^{\prime \prime} \mathrm{S}, 37^{\circ} 45^{\prime} 45^{\prime \prime} \mathrm{W}\right.$, at $194 \mathrm{~m}$ altitude). The climate of the region, according to Köppen's classification, is Bssh', very hot, semiarid, of the steppe type, with rainy season centered in April, May, and June (Sousa et al., 2010). The average meteorological data of the experimental period were obtained from an automatic meteorological station installed $6 \mathrm{~km}$ from the experimental area (Figure 1).

The soil of the experimental area was classified as a Luvissolo Crômico, i.e., a x, according Santos et al. (2013), with wavy topography and clayey texture - with granulometric values of 478.2, 98.0, and 423.8 $\mathrm{g} \mathrm{kg}^{-1}$ for sand, silt, and clay, respectively (Donagema et al., 2011). The soil chemical analyses (Silva, 2009) showed: $\mathrm{pH}\left(\mathrm{H}_{2} \mathrm{O}\right) 6.6,25.80 \mathrm{~g} \mathrm{~kg}^{-1}$ organic matter $(\mathrm{OM}), 0.34 \mathrm{dS} \mathrm{m}^{-1}$ electric conductivity (EC), 24.0 $\mathrm{mg} \mathrm{dm}{ }^{-3} \mathrm{P}, 0.4 \mathrm{cmol}_{\mathrm{c}} \mathrm{dm}^{-3} \mathrm{~K}^{+}, 0.1 \mathrm{cmol}_{\mathrm{c}} \mathrm{dm}^{-3} \mathrm{Na}^{+}$, $16.3 \mathrm{cmol}_{\mathrm{c}} \mathrm{dm}^{-3} \mathrm{Ca}^{2+}, 10.1 \mathrm{cmol}_{\mathrm{c}} \mathrm{dm}^{-3} \mathrm{Mg}^{2+}, 0.0 \mathrm{cmol}_{\mathrm{c}}$ $\mathrm{dm}^{-3} \mathrm{Al}^{3+}$, and $3.20 \mathrm{cmol}_{\mathrm{c}} \mathrm{dm}^{-3} \mathrm{H}+\mathrm{Al}$ for summer; and $\mathrm{pH}\left(\mathrm{H}_{2} \mathrm{O}\right) 7.1,34.7 \mathrm{~g} \mathrm{~kg}^{-1} \mathrm{OM}, 0.57 \mathrm{dS} \mathrm{m}^{-1} \mathrm{EC}, 26.0$ $\mathrm{mg} \mathrm{dm}{ }^{-3} \mathrm{P}, 0.4 \mathrm{cmol}_{\mathrm{c}} \mathrm{dm}^{-3} \mathrm{~K}^{+}, 0.3 \mathrm{cmol}_{\mathrm{c}} \mathrm{dm}^{-3} \mathrm{Na}^{+}, 18.6$ $\mathrm{cmol}_{\mathrm{c}} \mathrm{dm}^{-3} \mathrm{Ca}^{2+}, 8.2 \mathrm{cmol}_{\mathrm{c}} \mathrm{dm}^{-3} \mathrm{Mg}^{2+}, 0.0 \mathrm{cmol}_{\mathrm{c}} \mathrm{dm}^{-3}$ $\mathrm{Al}^{3+}$, and $0.00 \mathrm{cmol}_{\mathrm{c}} \mathrm{dm}^{-3} \mathrm{H}+\mathrm{Al}$ for winter.

The experiment was carried out in a randomized complete block design, with four replicates. The treatments consisted of four $\mathrm{N}$ rates $(0,80,160$, and $\left.240 \mathrm{~kg} \mathrm{ha}^{-1}\right), 15 \%$ applied at 15 days after emergence (DAE), 50\% at $20 \mathrm{DAE}$, and $35 \%$ at $40 \mathrm{DAE}$ through a Venturi-type fertilizer injector. A constant $\mathrm{Zn}$ rate of $2.0 \mathrm{~kg} \mathrm{ha}^{-1}$ was applied via fertigation in all treatments

Pesq. agropec. bras., Brasília, v.54, e00556, 2019

DOI: 10.1590/S1678-3921.pab2019.v54.00556 
(Sobral et al., 2007). The $\mathrm{N}$ and $\mathrm{Zn}$ rates were supplied by the fertilizers urea and zinc sulfate, respectively.

Each plot consisted of six lines of $6.0 \mathrm{~m}$ in length, spaced at $1.0 \mathrm{~m}$ apart, totaling an area of $36.0 \mathrm{~m}^{2}$ $(6.0 \times 6.0 \mathrm{~m})$. The four central lines, discarding a plant at each end, were considered the harvest area of the plot, totaling $22.4 \mathrm{~m}^{2}$.

Soil was prepared by harrowing twice across the field at an average depth of $20 \mathrm{~cm}$. Then, the plots were demarcated, and the Bt Feroz corn hybrid was sown manually at a spacing of $1.0 \times 0.2 \mathrm{~m}$, totaling 50 thousand plants per hectare, on $1 / 20 / 2016$ in summer and 6/17/2016 in winter.

A drip irrigation system, with a spacing of $0.2 \mathrm{~m}$ between emitters and an average flow of $1.2 \mathrm{~L} \mathrm{~h}^{-1}$, was used; the daily water depth was obtained through water balance, considering the precipitation and evapotranspiration of the crop (Santos et al., 2014). Rainfall accumulated $114 \mathrm{~mm}$ in summer and 110 $\mathrm{mm}$ in winter, whereas gross irrigation depths totaled

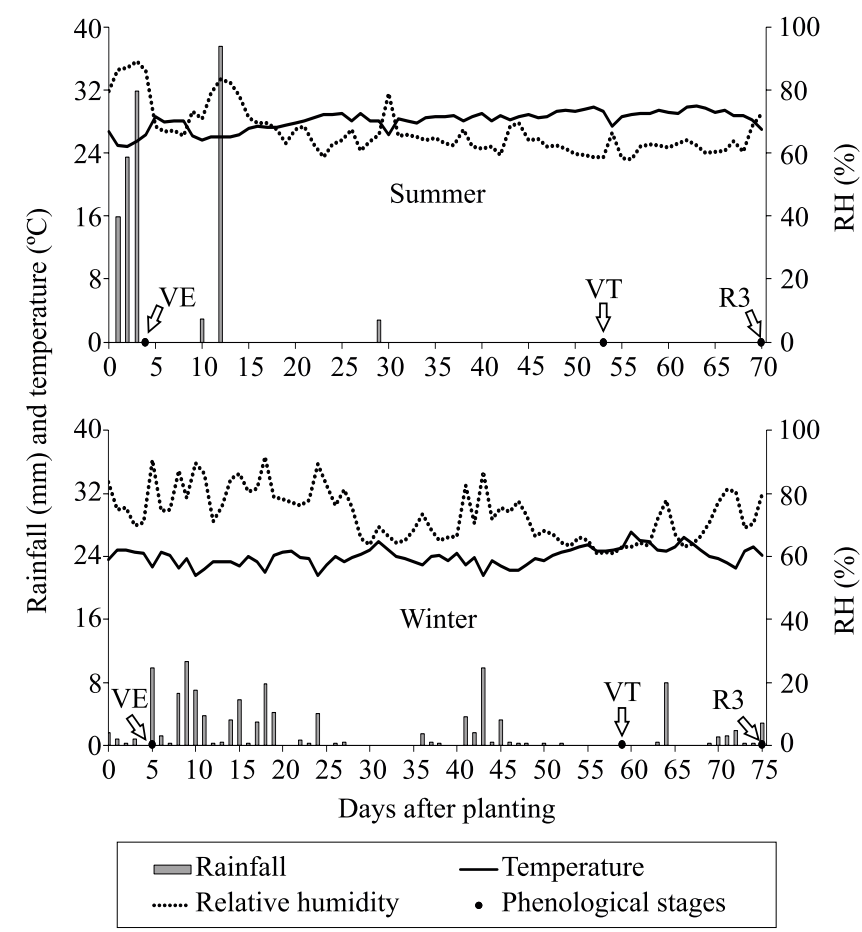

Figure 1. Rainfall, mean air temperature, and relative humidity $(\mathrm{RH})$ recorded during the experimental period and the phenological stages (VE, emergence; VT, tasseling; and R3, milky grains) of green corn (Zea mays) fertigated with nitrogen doses in the summer and winter of 2016, in the municipality of Canindé de São Francisco, in the state of Sergipe, in the Brazilian semiarid.
204 and $107 \mathrm{~mm}$ in the summer and winter seasons, respectively.

The cultural practices adopted during the experiments followed the standards used by the producers of the region. Weed control was performed with $500 \mathrm{~g} \mathrm{~L}^{-1}$ Atrazine herbicide, sprayed at 23 DAE.

Crops were harvested at the R3 phenological stage, which corresponded to 66 and 70 DAE in summer and winter, respectively, i.e., when the grains had a moisture content between 70 and $80 \%$. The number and mass of marketable green ears (Paiva et al., 2012) were evaluated in 28 plants present in the harvest area of each plot, by estimating the values per hectare.

Economic indicators were used to assess the efficiency of the treatments. The gross income was considered the value of the tradable ears per hectare at the time of harvest, i.e., on 3/30/2016 and 8/31/2016, being $\mathrm{R} \$ 0.40$ per ear for both crops. For each date, the US dollar (US\$) was quoted at R \$ 3.62 and at R \$ 3.23, respectively.

The total costs of 1 ha of corn for green ears were estimated, calculated, and analyzed at the end of each production process, adapting the method proposed by Companhia Nacional de Abastecimento (Conab, 2010). The expenses considered in the analysis included: variable costs, such as expenditure on crop costs (rent of machinery, labor, seeds, fertilizers, agrochemicals, and others); administrative expenses, technical assistance, rural land tax (RLT), financial expenses financing; fixed costs, including the depreciation and periodic maintenance of improvements/installations; and income from factors, such as expected remuneration on fixed capital and lease.

Administrative expenses and technical assistance corresponded, respectively, to 3 and $2 \%$ of the total cost of the crop, which was considered the minimum RLT to be paid in one agricultural year (R\$ 10.00), using the equation: $\operatorname{RLT}\left(\mathrm{R} \$ \mathrm{ha}^{-1}\right)=\operatorname{RLT}(\mathrm{R} \$) \times$ (culture cycle days/365 days).

The interest on financing was related to the resources required for the cost of the crop, computed from the respective periods of their release or use, considering the credit that the farmer obtained from the official rural credit for crop financing, with a rate of $7.49 \%$ per year, calculated according to the equation: interest $\left(\mathrm{R} \$ \mathrm{ha}^{-1}\right)=$ cost $\left(\mathrm{R} \$\right.$ ha $\left.^{-1}\right) \times($ culture cycle days $/ 365$ days $) \times 7.49 \%$.

To calculate the depreciation of improvements/ installations, the irrigation system designed for 1 ha 
corn was considered. It required $10,000 \mathrm{~m}$ of lowdensity polyethylene drip tapes, with emitters spaced at $0.20 \mathrm{~m}$ and with a nominal diameter of $16 \mathrm{~mm}$ (value of the new goods $=\mathrm{R} \$ 0.27 \mathrm{~m}^{-1}$ ), in addition to PVC pipes and connections (value of the new goods $=R \$ 3,952.80$ ). The useful life of the low-density polyethylene drip tape would be 2 years, and that of the pipes and fittings of 16 years (Cunha et al., 2012). Therefore, the depreciation of the irrigation system was obtained by: depreciation $\left(\mathrm{R} \$\right.$ ha $\left.^{-1}\right)=\left(\right.$ new goods $\left(\mathrm{R} \$\right.$ ha $\left.^{-1}\right) /$ useful life of goods in days) $x$ culture cycle days.

The periodic maintenance of improvements/ facilities (irrigation system) is an essential practice to maintain goods in good use conditions and in the best conditions to extend their useful life. To evaluate it, Conab (2010) recommends the following equation: maintenance $\left(\mathrm{R} \$\right.$ ha $\left.^{-1}\right)=$ new goods $\left(\mathrm{R} \$ \mathrm{ha}^{-1}\right) \times($ culture days $/ 365$ days) $\times 1 \%$, with a defined maintenance rate of $1 \%$.

The expected remuneration of the fixed capital immobilized by the producer is another factor that is part of the fixed cost of production. According to Conab (2010), the producer's investment must be remunerated and the percentage of $6 \%$ per year should be adopted as the rate of return as if the capital were applied in another alternative investment, using the equation: remuneration $\left(\mathrm{R} \$ \mathrm{ha}^{-1}\right)=$ value of the new goods $\left(\mathrm{R} \$\right.$ ha $\left.^{-1}\right) \times($ culture cycle days $/ 365$ days $) \times 6 \%$.

Land is one of the production factors. To calculate its cost, the value of the rent practiced in the region at the time of the study ( $\mathrm{R} \$ 3,000.00 \mathrm{ha}^{-1}$ per year) was considered, according to the equation: $\left(\mathrm{R} \$ \mathrm{ha}^{-1}\right)=$ rental value $\left(\mathrm{R} \$ \mathrm{ha}^{-1}\right) \mathrm{x}$ (culture cycle days/365 days).

The net income was calculated by the difference between the gross income and the total costs involved in obtaining the green corn ears. The rate of return was determined from the relationship between gross income and total costs, corresponding to the capital obtained for each Brazilian "real" applied in the cultivation of the crop.

For each crop season (summer and winter), analyses of variance of the characteristics were carried out through the Sisvar software, version 5.6 (Ferreira, 2011). Subsequently, a joint analysis was performed for the characteristics with homogeneity of variances between the harvests. The regression equations for the $\mathrm{N}$ rates and the averages of the crop seasons were compared by Tukey's test, at $5 \%$ probability.

\section{Results and Discussion}

For number and mass of marketable ears, there was an interaction between $\mathrm{N}$ rates and the evaluated harvests. In summer, the rates of 152.52 and 134.95 $\mathrm{kg} \mathrm{ha}^{-1} \mathrm{~N}$ promoted, respectively, maximum values of $41,183.84$ marketable ears per hectare and $8,746.94 \mathrm{~kg}$ $\mathrm{ha}^{-1}$ marketable ear mass, as observed in the quadratic equations (Figure 2). In the winter harvest of corn, the number $\left(53,291.25 \mathrm{ha}^{-1}\right)$ and mass $\left(12,945.80 \mathrm{~kg} \mathrm{ha}^{-1}\right)$ of marketable ears increased when fertigation was carried out with the optimal rates of 190.31 and $171.00 \mathrm{~kg} \mathrm{ha}^{-1}$ $\mathrm{N}$, respectively.

Similar results were obtained in other studies that evaluated $\mathrm{N}$ rates in the cultivation of green corn, aiming at the maximum yield of marketable ears, even under different cultivation conditions, such as planting season, soil type, cultivar, and source of N. In general, the authors recommended fertilization with $160 \mathrm{~kg} \mathrm{ha}^{-1}$ N (Silva et al., 2000, 2013; Araújo et al., 2014), which is close to the values suggested in the present study for maximum yields of 134.95-152.52 and 171.00-190.31 $\mathrm{kg} \mathrm{ha}^{-1} \mathrm{~N}$ for the summer and winter crops, respectively. It should be highlighted that these studies used manual or mechanical fertilization, showing that substituting them by fertigation would not reduce green corn yield.

The regression equations showed the existence of a zone of luxury consumption, i.e., the plant absorbs the applied nutrient, but does not respond in productivity (Figure 2), followed by an imbalance zone, considering that the higher $\mathrm{N}$ supply may have exceeded crop requirements, as well as intensified $\mathrm{NH}_{3}$ losses (Fernandes et al., 2005). N rates above $143.73 \mathrm{~kg} \mathrm{ha}^{-1}$ in the summer crop and $180.65 \mathrm{~kg} \mathrm{ha}^{-1}$ in the winter crop promoted a reduction in green corn production up to the highest evaluated rate of $240 \mathrm{~kg} \mathrm{ha}^{-1}$. Excessive $\mathrm{N}$ fertilizations may cause deleterious effects on nutrient availability to the crop, as they may possibly favor $\mathrm{NH}_{3}$ volatilization (Ma et al., 2010), especially in high temperature conditions (mean above $28^{\circ} \mathrm{C}$ ) and low relative humidity (mean lower than $67 \%$ ), as observed in the summer harvest (Tasca et al., 2011).

The reduction in the number and mass of marketable ears at the highest rate of $240 \mathrm{~kg} \mathrm{ha}^{-1} \mathrm{~N}$ may have been caused by the apparent low recovery of the applied nutrient (Pantoja et al., 2015), emphasizing the need to adjust fertilizer recommendations to as close as possible to the amount required by corn. In addition, the high fertigation of $\mathrm{N}$ in a soil with $\mathrm{pH}$ 
above 6.50 possibly intensified $\mathrm{NH}_{3}$ volatilization from urea application (Ma et al., 2010; Tasca et al., 2011). Therefore, researches on $\mathrm{NH}_{3}$ volatilization through the management of nitrogenous fertigation in clayey soils of neutral to alkaline $\mathrm{pH}$ and under high temperatures become important to indicate situations that can intensify the process. For the production of sweet corn (Z. mays var. saccharata), He et al. (2012) recommended more frequent irrigations with water depths of 5.0 to $7.5 \mathrm{~mm}$, the application of $168 \mathrm{~kg} \mathrm{ha}^{-1}$ $\mathrm{N}$, and fertilizations in the stages of large leaves $(1 / 4$ or $1 / 3$ of the rate) and of ear development ( $3 / 4$ or $2 / 3$ of the rate), besides an application rate between 30 and $40 \mathrm{~kg}$
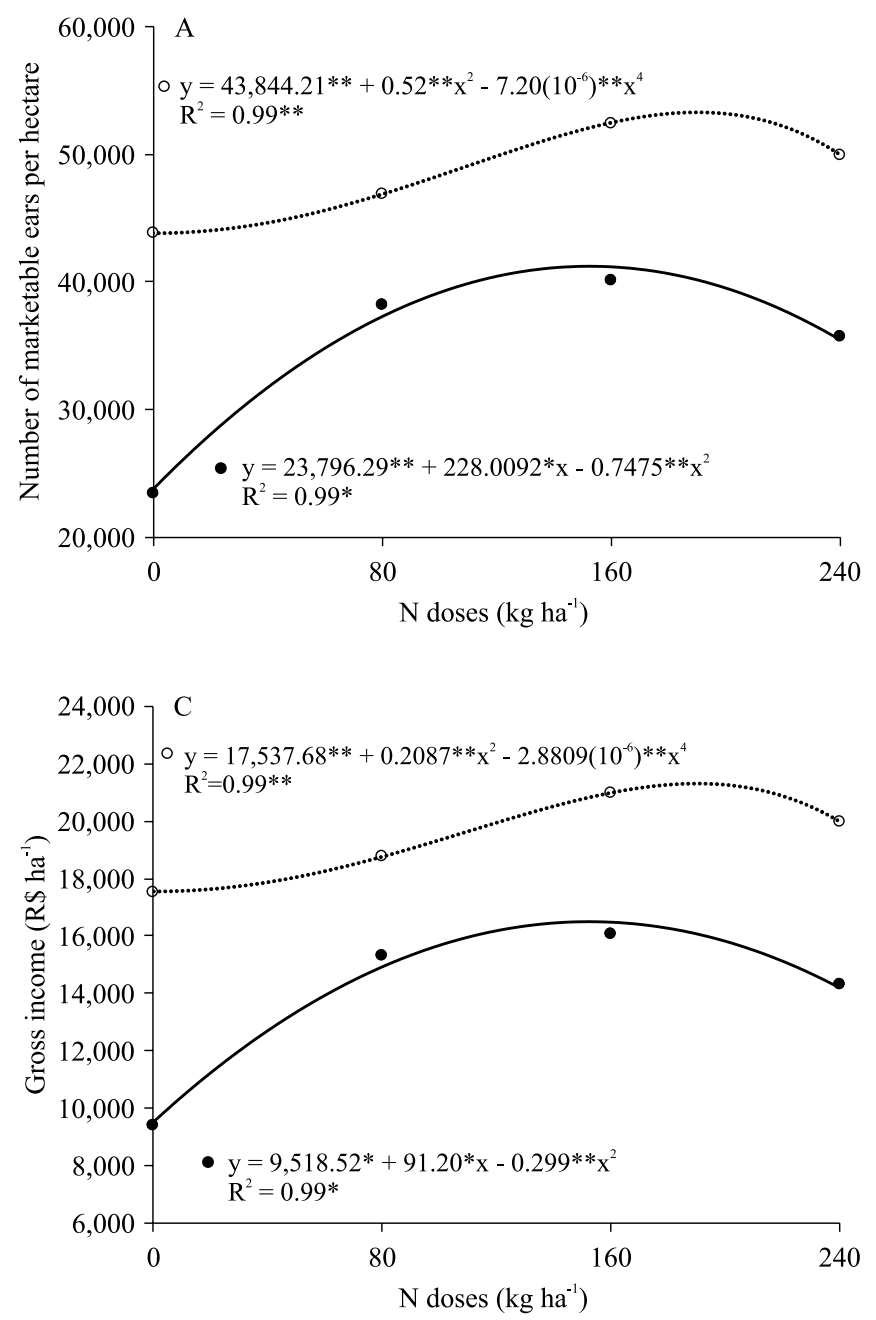

$\mathrm{ha}^{-1} \mathrm{~N}$ by fertigation, in order to avoid the leaching of $\mathrm{N}$ in the study conditions.

For all $\mathrm{N}$ rates assessed, the winter crop was superior to the summer crop (Table 1). In summer, the high temperature and low humidity probably contributed to a greater volatilization of $\mathrm{NH}_{3}$ from urea (Tasca et al., 2011; Souza et al., 2015a), which possibly affected negatively these variables. Moreover, overall solar radiation and the higher mean air temperature may have contributed to a decrease in $\mathrm{N}$ accumulation and, consequently, in the total production of ears of green corn, considering that the meteorological conditions of the season reduced the vegetative cycle of the crop to
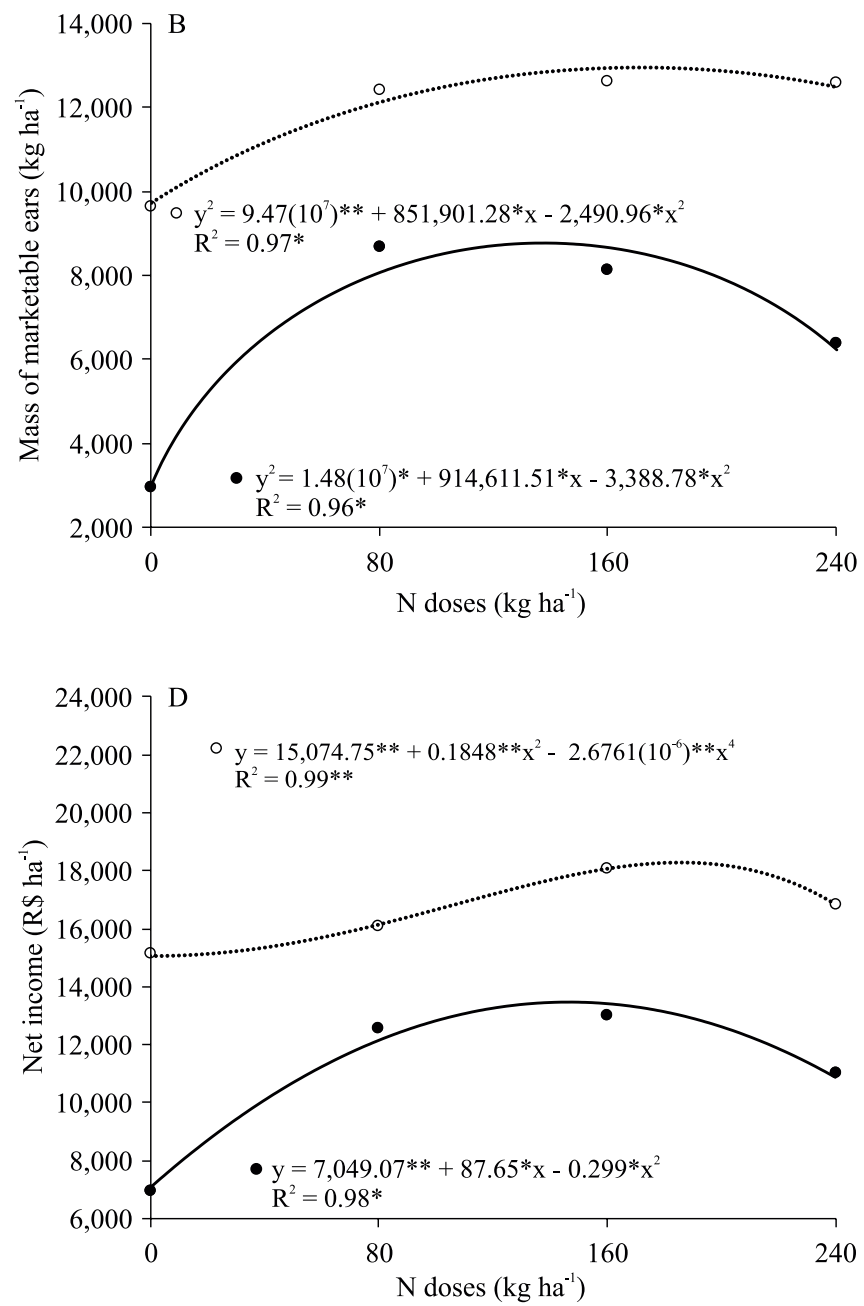

$$
\longrightarrow \text { Summer } \quad \cdots \cdots \cdots \cdots \cdots \cdots \cdots
$$

Figure 2. Number (A) and mass (B) of marketable ears, and gross (C) and net (D) incomes of green corn (Zea mays) fertigated with nitrogen rates in the summer and winter crop seasons, in the municipality of Canindé de São Francisco, in the state of Sergipe, in the Brazilian semiarid. 
only 53 days from planting to male flowering; in winter, tasseling occurred at 59 days after sowing (Figure 1).

Similar results were obtained by Paiva Junior et al. (2001), who evaluated the number of days for male blossoming of varieties for green corn production at distinct times in the municipality of Lavras, in the state of Minas Gerais, Brazil. The authors found that, in corn cropping in autumn-winter, the cultivars presented a delay in tasseling, which occurred at 79.90 days, when compared with the spring-summer planting, at 62.32 days. Rosa et al. (2016) also reported a longer corn cycle and higher ear yield in the years with lower air temperatures, as well as accelerated crop growth and reduced productivity with high temperatures.

Although the application of high $\mathrm{N}$ rates can cause high yields, it may not be economically feasible (Freire et al., 2010). Since the price paid for marketable green ears did not vary between harvests ( $\$ 0.40$ per ear), the gross income results had a similar statistical behavior to that of the number of tradable ears (Figure 2). The rates estimated at 152.52 and 190.31 $\mathrm{kg} \mathrm{ha}^{-1} \mathrm{~N}$ in summer and winter, respectively, reached maximum gross incomes of $\mathrm{R} \$ 16,473.53 \mathrm{ha}^{-1}$ and R\$ 21,316.45 ha-1, respectively. Furthermore, winter planting was more favorable to gross income, given the higher number of tradable ears obtained in this harvest (Table 1).
In Mossoró, in the state of Rio Grande do Norte, also in the Brazilian semiarid, Silva et al. (2013) recorded, in November 2009, R\$ $0.47 \mathrm{~kg}^{-1}$ marketable ear, achieving gross incomes of $\mathrm{R} \$ 6,314.42 \mathrm{ha}^{-1}$ without $\mathrm{N}$, $\mathrm{R} \$ 10,064.00 \mathrm{ha}^{-1}$ with $80 \mathrm{~kg} \mathrm{ha}^{-1} \mathrm{~N}$, and R $\$ 11,234.68$ ha $^{-1}$ with $160 \mathrm{~kg} \mathrm{ha}^{-1} \mathrm{~N}$. Paiva et al. (2012) obtained gross revenues between $\mathrm{R} \$ 18,718.00 \mathrm{ha}^{-1}$ without $\mathrm{N}$ and $\mathrm{R} \$ 50,402.51 \mathrm{ha}^{-1}$ with $120 \mathrm{~kg} \mathrm{ha}^{-1} \mathrm{~N}$ and $106 \mathrm{~kg}$ ha- $\mathrm{P}_{2} \mathrm{O}_{5}$, considering a value of sale of $\mathrm{R} \$ 3.50 \mathrm{~kg}^{-1}$ marketable ear, the trade price practiced in Mossoró in July 2011. Since the sale of green corn in Canindé de São Francisco is made from the unit price of the ear, the product was traded, on average, at $\mathrm{R} \$ 2.12 \mathrm{~kg}^{-1}$ in summer and $\mathrm{R} \$ 1.64 \mathrm{~kg}^{-1}$ in winter.

The total costs were estimated in $\mathrm{R} \$ 2,469.45$ without $\mathrm{N}, \mathrm{R} \$ 2,753.28$ with $80 \mathrm{~kg} \mathrm{ha}^{-1} \mathrm{~N}, \mathrm{R} \$ 3,037.11$ with $160 \mathrm{~kg} \mathrm{ha}^{-1} \mathrm{~N}$, and $\mathrm{R} \$ 3,320.95$ with $240 \mathrm{~kg} \mathrm{ha}^{-1}$ for the summer harvest; and in $\mathrm{R} \$ 2,422.12$ without $\mathrm{N}$, $\mathrm{R} \$ 2,668.34$ with $80 \mathrm{~kg} \mathrm{ha}^{-1} \mathrm{~N}, \mathrm{R} \$ 2,914.57$ with $160 \mathrm{~kg}$ $\mathrm{ha}^{-1} \mathrm{~N}$, and $\mathrm{R} \$ 3,160.79$ with $240 \mathrm{~kg} \mathrm{ha}^{-1} \mathrm{~N}$ in the winter harvest (Table 2).

Regarding total costs, the expenses with $\mathrm{N}$ fertilization corresponded to $9.69 \%$ for $80 \mathrm{~kg} \mathrm{ha}^{-1}$, $17.56 \%$ for $160 \mathrm{~kg} \mathrm{ha}^{-1}$, and $24.09 \%$ for $240 \mathrm{~kg} \mathrm{ha}^{-1}$ in the summer crop; and to $8.66 \%$ for $80 \mathrm{~kg} \mathrm{ha}^{-1}, 15.86 \%$ for $160 \mathrm{~kg} \mathrm{ha}^{-1}$, and $21.94 \%$ for $240 \mathrm{~kg} \mathrm{ha}^{-1}$ in the winter crop (Table 2). The main reason for this reduction in costs was related to the decrease in the price of urea

Table 1. Mean values of total ear mass, number and mass of marketable ears, and gross and net incomes of the interaction of crop seasons and nitrogen rates via fertigation in the production of green corn (Zea mays) in the Brazilian semiarid ${ }^{(1)}$.

\begin{tabular}{|c|c|c|c|c|}
\hline \multirow[t]{2}{*}{ Crop } & \multicolumn{4}{|c|}{$\mathrm{N}$ rate $\left(\mathrm{kg} \mathrm{ha}^{-1}\right)$} \\
\hline & 0 & 80 & 160 & 240 \\
\hline & \multicolumn{4}{|c|}{ Number of marketable ears (ears per hectare) } \\
\hline Summer & $23,456.79 b$ & $38,271.60 \mathrm{~b}$ & $40,123.46 b$ & $35,802.47 \mathrm{~b}$ \\
\hline \multirow[t]{2}{*}{ Winter } & $43,827.16 \mathrm{a}$ & $46,913.58 \mathrm{a}$ & $52,469.14 \mathrm{a}$ & $50,000.00 \mathrm{a}$ \\
\hline & \multicolumn{4}{|c|}{ Marketable ear mass $\left(\mathrm{kg} \mathrm{ha}^{-1}\right)$} \\
\hline Summer & $3,771.17 \mathrm{~b}$ & $8,685.18 b$ & $8,144.44 b$ & $6,384.26 b$ \\
\hline \multirow[t]{2}{*}{ Winter } & $9,655.86 \mathrm{a}$ & $12,431.05 \mathrm{a}$ & $12,628.77 \mathrm{a}$ & $12,582.41 \mathrm{a}$ \\
\hline & \multicolumn{4}{|c|}{ Gross income $\left(\mathrm{R} \$ \mathrm{ha}^{-1}\right)$} \\
\hline Summer & $9,382.72 b$ & $15,308.64 b$ & $16,049.38 b$ & $14,320.99 b$ \\
\hline \multirow[t]{2}{*}{ Winter } & $17,530.86 \mathrm{a}$ & $18,765.43 \mathrm{a}$ & $20,987.65 \mathrm{a}$ & $20,000.00 \mathrm{a}$ \\
\hline & \multicolumn{4}{|c|}{ Net income $\left(\mathrm{R} \$ \mathrm{ha}^{-1}\right)$} \\
\hline Summer & $6,913.27 \mathrm{~b}$ & $12,555.36 \mathrm{~b}$ & $13,012.27 b$ & $11,000.04 b$ \\
\hline Winter & $15,108.74 \mathrm{a}$ & $16,097.09 \mathrm{a}$ & $18,073.08 \mathrm{a}$ & $16,839.20 \mathrm{a}$ \\
\hline
\end{tabular}

${ }^{(1)}$ Means followed by equal letters, in the columns, do not differ by Tukey’s test, at 5\% probability 
(source of $\mathrm{N}$ ) from $\mathrm{R} \$ 1.50 \mathrm{~kg}^{-1}$ in summer to $\mathrm{R} \$ 1.30$ $\mathrm{kg}^{-1}$ in winter.

In general, labor costs were the most impacting on the cost of the crop in the absence of $\mathrm{N}$ fertilization and with fertilizations with 80 and $160 \mathrm{~kg} \mathrm{ha}^{-1} \mathrm{~N}$ (Table 2). On average, the participation of labor in the total costs of the corn crop was $20.85 \%$ in summer and $18.47 \%$ in winter. This difference was due to the irrigation management in each growing season, which required less time in winter. If the family provides labor, this expense would be transformed into net income for the activity. While evaluating the production costs of 1 ha of green corn, Zárate et al. (2009) observed higher labor costs, around $38.76 \%$ of total costs, since manual

Table 2. Total costs in the production of 1 ha of green corn (Zea mays) fertigated with nitrogen rates in two crop seasons in the Brazilian semiarid.

\begin{tabular}{|c|c|c|c|c|c|}
\hline \multirow{2}{*}{$\begin{array}{l}\text { Discrimination } \\
\text { I. Expenditure on crop cultivation costs }\end{array}$} & \multirow[t]{2}{*}{ Unit } & \multicolumn{2}{|c|}{ Summer } & \multicolumn{2}{|c|}{ Winter } \\
\hline & & Amount & $\mathrm{R} \$$ & Amount & $\mathrm{R} \$$ \\
\hline 1. Machine rental: tractor with plow grid & Hour & 2.00 & 220.00 & 2.00 & 220.00 \\
\hline \multicolumn{6}{|l|}{ 2. Labor } \\
\hline Distribution of drip tapes & Daily & 2.00 & 80.00 & 2.00 & 80.00 \\
\hline Manual planting with hoe & Daily & 1.00 & 40.00 & 1.00 & 40.00 \\
\hline Irrigation or fertigation & Hour & 34.00 & 170.00 & 18.00 & 90.00 \\
\hline Herbicide spraying & Daily & 1.00 & 40.00 & 1.00 & 40.00 \\
\hline Manual harvests of green ears & Daily & 6.00 & 240.00 & 6.00 & 240.00 \\
\hline 3. Seeds of the Bt Feroz corn hybrid & Kilogram & 15.00 & 417.40 & 15.00 & 391.40 \\
\hline \multicolumn{6}{|l|}{ 4. Fertilizers } \\
\hline Urea $(45 \% \mathrm{~N})-240 \mathrm{~kg} \mathrm{ha}^{-1} \mathrm{~N}$ & Kilogram & 533.34 & 800.01 & 533.34 & 693.34 \\
\hline Zinc sulphate $(21 \% \mathrm{Zn})$ & Kilogram & 9.53 & 34.69 & 9.53 & 34.69 \\
\hline 5. Pesticides: herbicide Atrazine & Liter & 4.00 & 112.00 & 4.00 & 100.00 \\
\hline 6. Others: soil analysis & Unit & 1.00 & 52.00 & 1.00 & 59.00 \\
\hline \multicolumn{6}{|l|}{ II. Other expenses } \\
\hline 7. Administrative expenses ( $3 \%$ of the cost of the crop) & & & 66.18 & & 59.65 \\
\hline 8. Technical assistance ( $2 \%$ of the cost of the crop) & & & 44.12 & & 39.77 \\
\hline 9. Rural land tax ( $\$ 10.00$ per year) & & & 1.92 & & 2.05 \\
\hline \multicolumn{6}{|l|}{ III. Financial expenses } \\
\hline 10. Interest on financing $(7.49 \%$ per year $)$ & & & 31.69 & & 30.60 \\
\hline Variable cost (I+II+III) & & & $2,350.01$ & & $2,120.50$ \\
\hline \multicolumn{6}{|l|}{ IV. Depreciation } \\
\hline 11. Depreciation of facilities & & & 306.28 & & 328.16 \\
\hline \multicolumn{6}{|l|}{ V. Other fixed costs } \\
\hline 12. Maintenance of facilities ( $1 \%$ per year) & & & 12.76 & & 13.67 \\
\hline Fixed cost $(\mathrm{IV}+\mathrm{V})$ & & & 319.04 & & 341.83 \\
\hline Operational cost (variable and fixed costs) & & & $2,669.05$ & & $2,462.33$ \\
\hline \multicolumn{6}{|l|}{ VI. Income from factors } \\
\hline 13. Remuneration on fixed capital ( $6 \%$ per year) & & & 76.55 & & 82.02 \\
\hline 14. Rent $\left(\mathrm{R} \$ 3,000.00 \mathrm{ha}^{-1}\right.$ per year) & & & 575.35 & & 616.44 \\
\hline \multicolumn{6}{|l|}{ Total cost (operational cost and income from factors) } \\
\hline $240 \mathrm{~kg} \mathrm{ha}^{-1} \mathrm{~N}$ & & & $3,320.95$ & & $3,160.79$ \\
\hline $160 \mathrm{~kg} \mathrm{ha}^{-1} \mathrm{~N}$ & & & $3,037.11$ & & $2,914.57$ \\
\hline $80 \mathrm{~kg} \mathrm{ha}^{-1} \mathrm{~N}$ & & & $2,753.28$ & & $2,668.34$ \\
\hline $0 \mathrm{~kg} \mathrm{ha}^{-1} \mathrm{~N}$ & & & $2,469.45$ & & $2,422.12$ \\
\hline
\end{tabular}


weeding was used to control invasive plants instead of herbicides.

The depreciation of the irrigation system also burdened total costs. The farmer needed to save $\mathrm{R} \$$ $306.28 \mathrm{ha}^{-1}$ in summer and R\$ $328.16 \mathrm{ha}^{-1}$ in winter to replace the drip tapes at the appropriate time, considering their lifespan of 2 years (Table 2), in order to avoid problems such as clogging emitters, which result in the low efficiency of the application of water and fertilizers.

The opportunity cost related to the rental of the property was also significant, as it corresponded, on average, to 20.12 and $22.30 \%$ of the total costs in the summer and winter harvests, respectively (Table 2). This expenditure was higher in the latter season due to the length of the corn cycle, which lasted 70 days from planting to harvesting of green ears, in summer, but 75 days in winter; however, the other costs were reduced, such as those with labor for irrigation, inputs, administrative expenses, technical assistance, and depreciation of facilities.

The net income from the production of green corn was obtained from the difference between the gross income and the total costs of production, reaching a maximum value of $\mathrm{R} \$ 13,473.50 \mathrm{ha}^{-1}$ in summer and of $\mathrm{R} \$ 18,266.30 \mathrm{ha}^{-1}$ in winter, associated with fertigation with 146.58 and $185.83 \mathrm{~kg} \mathrm{ha}^{-1} \mathrm{~N}$, respectively (Figure 2). It should be pointed out that the ideal $\mathrm{N}$ rates for net income showed reductions of only 3.89 and $2.35 \%$ in relation to those recommended for maximum gross income in the summer and winter crops, respectively.

In winter planting, the net incomes of green corn fertigated with different $\mathrm{N}$ rates were higher than those of the summer crop (Table 1). It is important to note that, in winter, the yield of tradable ears was higher and was associated with a lower production cost than in summer, maximizing the return on investment in green corn in the colder period.

There were isolated effects of $\mathrm{N}$ rates and harvests on the rate of return on investment in green corn. The $\mathrm{N}$ rates were represented by a quadratic equation, used to estimate a maximum value of $\mathrm{R} \$ 6.17$ per invested real, when the corn plants were fertigated with 90 $\mathrm{kg} \mathrm{ha}^{-1} \mathrm{~N}$ (Figure 3). The rate of return for the winter crop was 6.95, higher than that of 4.50 for the summer crop. These results show the economic viability of the investment, in which, for each real invested, the farmer obtained up to R $\$ 6.95$ return, which could be used for

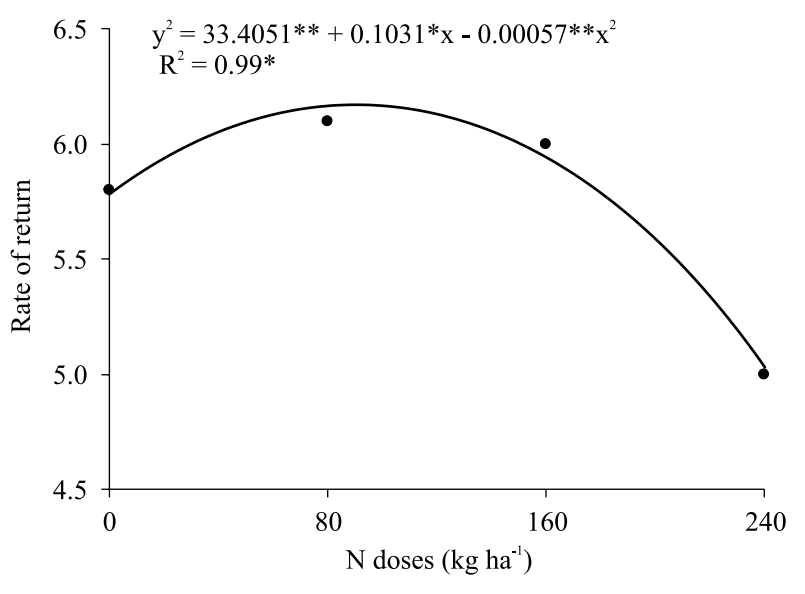

Figure 3. Rate of return of green corn (Zea mays) fertigated with nitrogen rates in the Brazilian semiarid.

investment in a drip-irrigation system, facilitating and making flexible the application of soluble fertilizers via fertigation.

The rate of return is very important because, when relating gross income to production costs, it can express the potential return of the capital to be obtained with the enterprise. Zárate et al. (2009) and Begum et al. (2015) found rates of return lower than 3.05 in the production of green corn, with a low remuneration for the product associated with high expenses, despite having achieved satisfactory productivities of over 40 thousand commercially available ears per hectare.

By the regression equations obtained, it would be agronomically safe and economical to apply $90 \mathrm{~kg}$ $\mathrm{ha}^{-1} \mathrm{~N}$ in both growing seasons, since it would allow a rate of return of 6.17. It should be pointed out that this rate is lower than the $100 \mathrm{~kg} \mathrm{ha}^{-1} \mathrm{~N}$ recommended by Sobral et al. (2007) for the plantation of rainfed corn in the east of the state of Sergipe, but higher than that of $60 \mathrm{~kg} \mathrm{ha}^{-1} \mathrm{~N}$ indicated for the west region of the state.

Regardless of $\mathrm{N}$ rates, the rate of return of the green corn crop, in both seasons, was superior to 5.80, showing the agronomic and economic feasibility of the production of this crop under the Brazilian semiarid conditions evaluated.

\section{Conclusions}

1. In the Brazilian semiarid, the maximum productivity of green corn (Zea mays) with a lower 
production cost is reached with fertigation with $90 \mathrm{~kg}$ $\mathrm{ha}^{-1}$ nitrogen, in both summer and winter harvests.

2. The fertigation of corn with the highest $\mathrm{N}$ rate of $240 \mathrm{~kg} \mathrm{ha}^{-1}$ promotes a lower financial rate of return.

3 . The winter crop promotes higher productivity and profitability of green ears when corn is fertigated with $160 \mathrm{~kg} \mathrm{ha}^{-1} \mathrm{~N}$ in the Brazilian semiarid.

\section{Acknowledgments}

To Coordenação de Aperfeiçoamento de Pessoal de Nível Superior (Capes), for a doctoral scholarship.

\section{References}

ARAÚJO, R.M.; ARAÚJO, A.S.F. de; NUNES, L.A.P.L.; FIGUEIREDO, M. do V.B. Resposta do milho verde à inoculação com Azospirillum brasiliense e níveis de nitrogênio. Ciência Rural, v.44, p.1556-1560, 2014. DOI: https://doi.org/10.1590/0103$8478 \mathrm{cr} 20130355$.

BEGUM, A.A.; ISLAM, M.N.; KAKON, S.S.; KAMAL, M.A.H.M.; AZIZ, M.A.; PAUL, S.K. Effect of sowing date of sweet corn on potato + sweet corn intercropping system. Bangladesh Agronomy Journal, v.18, p.15-21, 2015. DOI: https:// doi.org/10.3329/baj.v18i2.28899.

CLAY, D.E.; MALZER, G.L.; ANDERSON, J.L. Ammonia volatilization from urea as influenced by soil temperature, soil water content, and nitrification and hydrolysis inhibitors. Soil Science Society of America, v.54, p.263-266, 1990. DOI: https:// doi.org/10.2136/sssaj1990.03615995005400010042x.

CONAB. Companhia Nacional de Abastecimento. Custos de produção agrícola: a metodologia da CONAB. Brasília, 2010. 58p.

CUNHA, J.L. de O.; PORDEUS, R.V.; SILVA JR, M.J. da; PONTES, F.S.T.; AZEVEDO, C.A.V. de. Impactos econômicos da depreciação de sistemas de irrigação por gotejamento nos custos de produção agrícola. Enciclopédia Biosfera, v.8, p.1008-1020, 2012.

DANTAS, D.F. da S.; OLIVEIRA, A.P. de; BANDEIRA, N.V. da S.; PINHEIRO, S.M.G.; DANTAS, T.A.G.; SILVA, O.P.R. da. Produtividade de espigas e grãos verdes de milho adubado com fontes e doses de nitrogênio. Revista Agropecuária Técnica, v.35, p.100-105, 2014.

DONAGEMA, G.K.; CAMPOS, D.V.B. de; CALDERANO, S.B.; TEIXEIRA, W.G.; VIANA, J.H.M. (Org.). Manual de métodos de análises de solos. 2.ed. Rio de Janeiro: Embrapa Solos, 2011. p.43-49.

FERNANDES, F.C.S.; BUZETTI, S.; ARF, O.; ANDRADE, J.A. da C. Doses, eficiência e uso de nitrogênio por seis cultivares de milho. Revista Brasileira de Milho e Sorgo, v.4, p.195-204, 2005. DOI: https://doi.org/10.18512/1980-6477/rbms.v4n2p195-204.

FERREIRA, D.F. Sisvar: a computer statistical analysis system. Ciência e Agrotecnologia, v.35, p.1039-1042, 2011. DOI: https:// doi.org/10.1590/S1413-70542011000600001.
FREIRE, F.M.; VIANA, M.C.M.; MASCARENHAS, M.H.T.; PEDROSA, M.W.; COELHO, A.M.; ANDRADE, C.L.T. de. Produtividade econômica e componentes da produção de espigas verdes de milho em função da adubação nitrogenada. Revista Brasileira de Milho e Sorgo, v.9, p.213-222, 2010. DOI: https:// doi.org/10.18512/1980-6477/rbms.v9n3p213-222.

HE, J.; DUKES, M.D.; HOCHMUTH, G.J.; JONS, J.W.; GRAHAM, W.D. Identifying irrigation and nitrogen best management practices for sweet corn production on sandy soils using CERES-Maize model. Agricultural Water Management, v.109, p.61-70, 2012. DOI: https://doi.org/10.1016/j. agwat.2012.02.007.

KUMAR, M.; RAJPUT, T.B.S.; KUMAR, R.; PATEL, N. Water and nitrate dynamics in baby corn (Zea mays L.) under different fertigation frequencies and operating pressures in semi-arid region of India. Agricultural Water Management, v.163, p.263274, 2016. DOI: https://doi.org/10.1016/j.agwat.2015.10.002.

LIU, G.; LI, Y.; ALVA, A.K. High water regime can reduce ammonia volatilization from soils under potato production. Communicationsin Soil Science and Plant Analysis, v.38, p.12031220, 2007. DOI: https://doi.org/10.1080/00103620701328289.

MA, B.L.; WU, T.Y.; TREMBLAY, N.; DEEN, W.; MCLAUGHLIN, N.B.; MORRISON, M.J.; STEWART, G. Onfarm assessment of the amount and timing of nitrogen fertilizer on ammonia volatilization. Agronomy Journal, v.102, p.134-144, 2010. DOI: https://doi.org/10.2134/agronj2009.0021.

MONTEIRO, A.L.; SILVA, P.S.L.; TAVELLA, L.B.; OLIVEIRA, F.H.T.; SILVA, P.I.B. Mimosa caesalpiniifolia intercropping, weeds removal after hoeing and nitrogen fertilization on maize. Horticultura Brasileira, v.34, p.175-182, 2016. DOI: https:/doi. org/10.1590/S0102-053620160000200005.

PAIVA JUNIOR, M.C. de; VON PINHO, R.G.; VON PINHO, É.V. de R.; RESENDE, S.G. de. Desempenho de cultivares para a produção de milho verde em diferentes épocas e densidades de semeadura em Lavras-MG. Ciência e Agrotecnologia, v.25, p.1235-1247, 2001

PAIVA, M.R. de F.C.; SILVA, G.F. da; OLIVEIRA, F.H.T. de; PEREIRA, R.G.; QUEIROGA, F.M. de. Doses de nitrogênio e de fósforo recomendadas para produção econômica de milho-verde na Chapada do Apodi-RN. Revista Caatinga, v.25, p.1-10, 2012.

PANTOJA, J.L.; WOLI, K.P.; SAWYER, J.E.; BARKER, D.W. Corn nitrogen fertilization requirement and corn-soybean productivity with a rye cover crop. Soil Science Society of America Journal, v.79, p.1482-1495, 2015. DOI: https://doi. org/10.2136/sssaj2015.02.0084.

ROSA, R.; KOSTERNA-KELLE, E.; FRANCZUK, J.; ZNIEWICZ-BAJKOWSKA, A. The influence of weather conditions of eastern Poland on sweet corn yields and length of growing season. Journal of Ecological Engineering, v.17, p.273279, 2016. DOI: https://oi.org/10.12911/22998993/64501.

SAMPATHKUMAR, T.; PANDIAN, B.J. Effect of fertigation frequencies and levels on growth and yield of maize. Madras Agricultural Journal, v.97, p.245-248, 2010.

SANTOS, H.G. dos; JACOMINE, P.K.T.; ANJOS, L.H.C. dos; OLIVEIRA, V.Á. de; LUMBRERAS, J.F.; COELHO, M.R.; 
ALMEIDA, J.A. de; CUNHA, T.J.F.; OLIVEIRA, J.B. de. Sistema brasileiro de classificação de solos. 3.ed. rev. amp. Brasília: Embrapa, 2013. 353p.

SANTOS, W. de O.; ESPÍNOLA SOBRINHO, J.; MEDEIROS, J.F. de; MOURA, M.S.B. de; NUNES, R.L.C. Coeficientes de cultivo e necessidades hídricas da cultura do milho verde nas condições do semiárido brasileiro. Irriga, v.19, p.559-572, 2014. DOI: https://doi.org/10.15809/irriga.2014v19n4p559.

SENGIK, E.; KIEHL, J. de C.; SILVA, M.A.G. da; PALANGANA, D.C.; LAWDER, M.R. Perdas de amônia em solo e de resíduos orgânicos autoclavados e tratados com ureia. Acta Scientiarum. Agronomy, v.23, p.1099-1105, 2001. DOI: https://doi.org/10.4025/ actasciagron.v23i0.2565.

SILVA, F.C. da (Ed.). Manual de análises químicas de solos, plantas e fertilizantes. 2.ed. rev. ampl. Brasília: Embrapa Informação Tecnológica, 2009. 627p.

SILVA, P.S.L. e; DINIZ FILHO, E.T.; GRANGEIRO, L.C.; DUARTE, S.R. Efeitos de níveis de nitrogênio e da aplicação de deltametrina sobre os rendimentos de espigas verdes e de grãos de milho. Revista Ceres, v.47, p.75-87, 2000.

SILVA, P.S.L.; ARAÚJO JÚNIOR, B.B.; OLIVEIRA, V.R.; PONTES, F.S.T.; OLIVEIRA, O.F. Effects of nitrogen application on corn yield after harvesting the apical ear as baby corn. Horticultura Brasileira, v.31, p.419-425, 2013. DOI: https://doi. org/10.1590/S0102-05362013000300012.

SOBRAL, L.F.; CARVALHO, H.W.L.; BARRETO, A.C.; ANJOS, J.L. dos. Milho. In: SOBRAL, L.F.; VIEGAS, P.R.A.; SIQUEIRA, O.J.W. de; ANJOS, J.L. dos; BARRETO, M.C. de V.; GOMES, J.B.V. (Ed.). Recomendações para o uso de corretivos e fertilizantes no Estado de Sergipe. Aracaju: Embrapa Tabuleiros Costeiros, 2007. p.201-203.

SOUSA, I.F. de; SILVA, V. de P.R. da; SABINO, F.G.; NETTO, A. de O.A.; SILVA, B.K.N.; AZEVEDO, P.V. de. Evapotranspiração de referência nos perímetros irrigados do estado de Sergipe. Revista Brasileira de Engenharia Agrícola e Ambiental, v.14, p.633-644, 2010. DOI: https://doi.org/10.1590/S141543662010000600010.

SOUZA, E.J. de; CUNHA, F.F. da; MAGALHÃES, F.F.; SILVA, T.R. da; SANTOS, O.F. dos. Effect of irrigation and nitrogen fertilization on agronomic traits of sweet corn. Pesquisa Agropecuária Tropical, v.45, p.282-290, 2015a. DOI: https://doi. org/10.1590/1983-40632015v4533628.

SOUZA, J.A.; BUZETTI, S.; MOREIRA, A. Viabilidade econômica de fontes e doses de nitrogênio no cultivo do milho segunda safra em sistema de plantio direto. Revista de Ciências Agrárias - Amazonian Journal of Agricultural and Environmental Sciences, v.58, p.308-313, 2015b. DOI: https:// doi.org/10.4322/rca.1921.

TASCA, F.A.; ERNANI, P.R.; ROGERI, D.A.; GATIBONI, L.C.; CASSOL, P.C. Volatilização de amônia do solo após a aplicação de ureia convencional ou com inibido de urease. Revista Brasileira de Ciência do Solo, v.35, p.493-502, 2011. DOI: https://doi. org/10.1590/S0100-06832011000200018.

VON PINHO, R.G.; BORGES, I.D.; PEREIRA, J.L. de A.R.; REIS, M.C. dos. Marcha de absorção de macronutrientes e acúmulo de matéria seca em milho. Revista Brasileira de Milho e Sorgo, v.8, p.157-173, 2009. DOI: https://doi.org/10.18512/19806477/rbms.v8n02p\%25p.

YUAN, M.; RUARK, M.D.; BLAND, W.L. Adaption of the AmaizeN model for nitrogen management in sweet corn (Zea mays L.). Field Crops Research, v.209, p.27-38, 2017. DOI: https://doi.org/10.1016/j.fcr.2017.04.007.

ZÁRATE, N.A.H.; VIEIRA, M. do C.; SOUSA, T.M. de; RAMOS, D.D. Produção e renda líquida de milho verde em função da época de amontoa. Semina: Ciência Agrárias, v.30, p.95-100, 2009.

ZHOU, B.; YUE, Y.; SUN, X.; DING, Z.; MA, W.; ZHAO, M. Maize kernel weight responses to sowing date-associated variation in weather conditions. The Crop Journal, v.5, p.43-51, 2017. DOI: https://doi.org/10.1016/j.cj.2016.07.002.

Pesq. agropec. bras., Brasília, v.54, e00556, 2019

DOI: 10.1590/S1678-3921.pab2019.v54.00556 